\title{
Optical Coherence Tomography Retinal Nerve Fiber Analysis: A Measure of Axon Loss in Multiple Sclerosis
}

\author{
Aileen Antonio-Santos M.D., Eric R. Eggenberger ${ }^{*}$, Fiona Costello M.D., Laura Balcer M.D. \\ Department of Neurology \& Ophthalmology, Michigan State University, USA
}

Copyright $(2016$ by authors, all rights reserved. Authors agree that this article remains permanently open access under the terms of the Creative Commons Attribution License 4.0 International License

\begin{abstract}
Objective to investigate whether optical coherence tomography (OCT) could demonstrate axonal loss through thinning of the retinal nerve fiber layer (RNFL) in multiple sclerosis (MS) patients. Furthermore, the degree of RNFL loss was compared in the different MS subgroups (with or without optic neuritis, affected or fellow eye, single episode or recurrent optic neuritis, relapsing remitting or progressive MS). RNFL thinning was also determined in MS patients who had serial OCT without any intervening clinical optic neuritis. Design: Retrospective chart review. Setting: Academic tertiary care MS centers. Participants: 177 patients (334 eyes) with multiple sclerosis, with or without optic neuritis, and 159 healthy controls that underwent OCT RNFL measurements. Main Outcome: Retinal nerve fiber layer measurements by OCT. Results: Average RNFL measurements were thinner in MS patients $(90 \mu \mathrm{m})$ compared to controls $(105 \mu \mathrm{m}), \mathrm{p}<0.0001$. RNFL was significantly reduced in MS patients with optic neuritis (87 $\mu \mathrm{m})$ versus those without optic neuritis $(94 \mu \mathrm{m}), \mathrm{p}<0.0001$. Among the different quadrants, the degree of RNFL loss was greatest in the temporal quadrant of MS patients $(22 \%)$. Progressive (primary and secondary progressive) MS patients had thinner RNFL $(82 \mu \mathrm{m})$ compared to all relapsing remitting MS patients $(90 \mu \mathrm{m}), \mathrm{p}<0.0001$. Greater RNFL loss was seen in SPMS patients $(77 \mu \mathrm{m})$ versus PPMS (88 $\mu \mathrm{m}), \mathrm{p}=0.004$. In the $45 \mathrm{MS}$ patients without any intervening clinical optic neuritis, serial OCT (mean of 2 OCT scans per patients, averaging 11 months apart) showed that RNFL decreased by $3.7 \mu \mathrm{m}$ per year. Conclusion: Retinal nerve fiber layer is significantly reduced in patients with multiple sclerosis. Progressive MS subtypes showed more marked RNFL thinning than relapsing remitting MS. This study reflects the role of OCT in MS patient monitoring and its potential as a surrogate marker in MS therapeutic trials.
\end{abstract}

Keywords Optical Coherence Tomography (OCT), Multiple Sclerosis (MS), Retinal Nerve Fiber Layer (RNFL), Optic Neuritis, Optic Atrophy, RNFL Loss, RNFL Thinning

\section{Introduction}

Optic neuritis-mediated visual loss is the initial symptom in $20 \%$ of patients with multiple sclerosis (MS)1,2 and occurs at some stage in the course of MS in approximately $75 \%$ of patients.3,4 In the Optic Neuritis Treatment Trial (ONTT), the entrance visual acuity (VA) varied considerably, with VA worse than $20 / 50$ in $65 \%$ of patients, 5 however, VA spontaneously improved to $20 / 40$ or better in $64 \%$ of patients at 6 months. 6 At 6 months, $63 \%$ of patients perceived their vision to be somewhat or much worse that it was before the onset of optic neuritis. 7 Clinical post-mortem data, 8 animal models9,10 and magnetic resonance imaging (MRI)11,12 have demonstrated optic nerve atrophy after optic neuritis and MS.

Although MRI has been a valuable tool for diagnosis and monitoring of disease progression, 13 traditional MRI findings do not correlate well with clinical disability, comprising the "clinical-MRI paradox". 14 Gadolinium-enhancing lesions and progressive brain atrophy may occur subclinically.15-17 Histopathology of MS lesions and normal-appearing white matter (NAWM), 18-20 including the anterior visual pathway, 21 show irreversible axonal loss, which appear to be an early and persistent event in MS.22 This atrophy and axonal loss correlate better with disability, however, the capability of conventional MRI techniques to accurately assess these features of MS is limited. A non-invasive in-vivo biological marker that could specifically and accurately quantify axon loss secondary to the disease process is needed to follow the course and monitor treatment effects.

The optic nerve represents a common MS target. The retinal nerve fiber layer ( $R N F L$ ) is a unique neuroanatomic model because it is devoid of myelin, visible in vivo, and contains the central nervous system axons of retinal ganglion cells, which coalesce at the optic nerve head to form the myelinated optic nerve. Optical coherence tomography is an 
in-vivo non-contact instrument that qualitatively and quantitatively measures the changes of the peripapillary RNFL and optic nerve in an accurate, precise and reproducible manner.23,24 [figure 1]. Cross-sectional micron-resolution imaging of the internal ocular tissues by measuring the echo time delay of back-scattered infrared light using an interferometer and a low-coherence light source is produced. The technology is similar to ultrasound, but it uses light instead of acoustic energy.
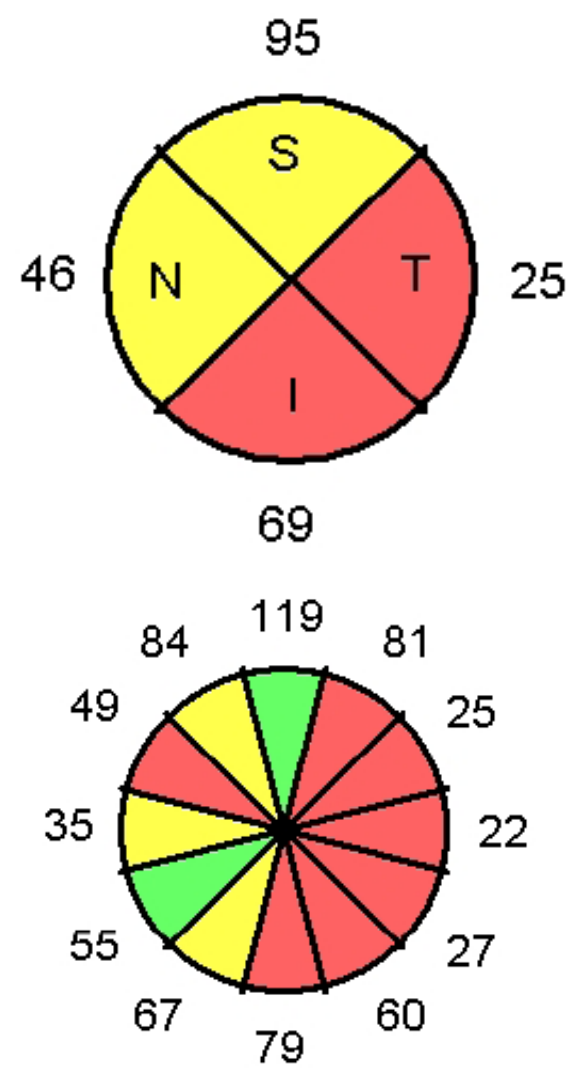

Figure 1. OCT images in a case of optic neuritis 9 months after onset with recovered acuity of 20/20 demonstrate regional atrophy (red wedges) and borderline thinning (yellow wedges) in sectoral (left) and quadrant (right) images

Our aim was to investigate whether optical coherence tomography could demonstrate axonal loss through thinning of the retinal nerve fiber layer of patients with multiple sclerosis. We also compared the degree of RNFL loss among the different subgroups of MS patients (relapsing-remitting MS and progressive MS), in MS patients with a single episode or recurrent optic neuritis to those without a history of optic neuritis, and the eyes affected with optic neuritis to the fellow eye.

\section{Methods}

Patients

This is a retrospective chart review of 177 patients with multiple sclerosis, meeting the Poser25 or McDonald26 criteria, with or without optic neuritis, seen at the Neuro-Ophthalmology Clinics at the Michigan State University or at the University of Ottawa from 2003 to 2007. All patients were evaluated by a neuro-ophthalmologist (EE or FC). Subjects were excluded if they had an anomalous optic nerve, concomitant retinal or non-optic neuritis optic nerve disease or had poor OCT scan quality. Healthy controls were recruited from family members of patients and from hospital staff; those with known ophthalmologic or other neurologic disease were excluded. Approval for the study was obtained from the respective institutional review boards.

\section{Optical Coherence Tomography}

Retinal nerve fiber layer (RNFL) measurements were performed with the Stratus OCT (model 3000, software version 4.0; Carl Zeiss Meditec, Dublin, CA). The basic principle and technical characteristics of Stratus OCT have been reported previously.27-29 The fast retinal nerve fiber layer thickness algorithm, consisting of three $360^{\circ}$ circular scans with a diameter of $3.4 \mathrm{~mm}$ centered on the optic disc, was performed. If the pupils of the patient were large enough to allow adequate OCT imaging, scanning was completed without pupil dilatation; otherwise the pupils were dilated. Eyes affected with clinical optic neuritis were scanned at least nine months after the attack to allow for resolution of acute inflammation and evolution of atrophy; further recovery of the optic nerve is less likely after this time period.30 OCT scans were accepted only if: the fundus image was clear enough to see the optic disc centered in the scan circle, color saturation was even and dense across the entire scan with red in the retinal pigment epithelium and RNFL, there were no missing or blank area within the scan pattern, and signal strength of at least 6.18,23 The following RNFL parameters were analyzed: average thickness $\left(360^{\circ}\right.$ measurement), temporal quadrant thickness $\left(316^{\circ}\right.$ to $\left.45^{\circ}\right)$, superior quadrant thickness $\left(46^{\circ}\right.$ to $\left.135^{\circ}\right)$, nasal quadrant thickness $\left(136^{\circ}\right.$ to $\left.225^{\circ}\right)$, and inferior quadrant thickness $\left(226^{\circ}\right.$ to $\left.315^{\circ}\right)$.

\section{Statistical Analysis}

Data analyses were performed using Stata 10.0 software (StataCorp, College Station, TX). Two-sample t-tests were used to compare groups of eyes with respect to RNFL thickness.

\section{Results}

\section{Demographics}

A total of 338 eyes (177 patients with multiple sclerosis) was analyzed, 54\% from the Michigan State University and $46 \%$ from the University of Ottawa. The patients' mean age was $43.4 \pm 10.95$ years (range: $14-76$ ), and 62\% were females. A prior history of optic neuritis was present in 92 $(53 \%)$ of this cohort. Of these, 15 patients (24 eyes) had 
recurrent attacks of optic neuritis, with a range of 1 to 5 recurrences. Relapsing-remitting MS (RRMS) was diagnosed in 150 patients $(85 \%)$, primary progressive MS (PPMS) in 12 (7\%) and secondary progressive MS (SPMS) in $15(8 \%)$. At the time of the study, $63 \%$ of patients were receiving treatment: $34 \%$ on interferon and $22 \%$ on Glatiramer.

Optical Coherence Tomography Retinal Nerve Fiber Layer (OCT RNFL) Thickness

Overall, the average RNFL thickness was significantly reduced in patients with MS (mean $=90.25 \pm 17.08 \mu \mathrm{m}$ ) compared to controls (mean $=105.02 \pm 11.10), \mathrm{p}<0.0001$. All quadrant RNFL measurements were also thinner in MS patients compared to controls, $\mathrm{p}<0.0001$ (Table 1).

Optical Coherence Tomography Retinal Nerve Fiber Layer (OCT RNFL) Thickness in MS Patients with or without Optic Neuritis

The average RNFL thickness was decreased in MS patients without optic neuritis (MS sans ON) (mean $=94.41$ $\pm 15.36 \mu \mathrm{m})$ versus controls (mean $=105.02 \pm 11.10 \mu \mathrm{m}), \mathrm{p}$ $<0.0001$ and was even thinner in MS patients affected with optic neuritis $(\mathrm{MSON})($ mean $=86.84 \pm 17.53 \mu \mathrm{m})$ versus controls (mean $=105.02 \pm 11.10 \mu \mathrm{m}), \mathrm{p}<0.0001$ (Table 1$)$. The average RNFL in MS patients with optic neuritis (MSON) was significantly thinner than those without optic neuritis (MS sans ON), $p<0.0001$. Average RNFL thickness was reduced by $25 \mu \mathrm{m}(15 \%)$ in MSON and $11 \mu \mathrm{m}(10 \%)$ in MS sans ON vs. controls. The RNFL thickness in all quadrants was within normal limits, defined as being within the 5th to 95 th percentile of age-matched normative control eyes, in $48 \%$ of MS w/o ON and in $23 \%$ of MSON. Compared to controls (mean $=74.35 \pm 12.31 \mu \mathrm{m}$ ), RNFL loss was present in all quadrants of MS sans ON, p-value range $<0.0001$ to 0.0002 , and these were more severely affected in MSON, $\mathrm{p}<0.0001$. In MS patients with optic neuritis, quadrant RNFL measurements were significantly thinner compared to MS patients without optic neuritis, p-value range $<0.0001$ to 0.01 (Table 1). Affected eyes of MS patients with optic neuritis had significantly thinner RNFL compared to fellow eyes, $\mathrm{p}<0.0001$ (Table 1); among the quadrant measurements, only the temporal quadrant in the fellow eyes had a decreased RNFL compared to MS patients without a prior history of clinical optic neuritis (Table 1).

Table 1. OCT RNFL measurements in control, all MS patients, MS sans optic neuritis, MS with optic neuritis, MS affected eye, MS fellow eye, MS recurrent optic neuritis

\begin{tabular}{|c|c|c|c|c|c|c|c|}
\hline OCT-RNFL & $\begin{array}{c}\text { Control } \\
(\mathrm{n}=159)\end{array}$ & $\begin{array}{c}\text { All MS patients } \\
(\mathrm{n}=334)\end{array}$ & $\begin{array}{c}\text { MS sans ON } \\
(\mathrm{n}=169)\end{array}$ & $\begin{array}{c}\text { MS with ON } \\
(\mathrm{n}=159)\end{array}$ & $\begin{array}{c}\text { MS affected } \\
\text { eye } \\
(\mathrm{n}=99)\end{array}$ & $\begin{array}{c}\text { MS fellow eye } \\
(\mathrm{n}=70)\end{array}$ & $\begin{array}{c}\text { MS recurrent } \\
\text { ON } \\
(\mathrm{n}=27)\end{array}$ \\
\hline $\begin{array}{c}\text { Average } \\
\text { thickness }\end{array}$ & $105.02 \pm 11.10$ & $\begin{array}{c}90.25 \pm 17.08 \\
\mathrm{p}^{\mathrm{a}}<0.0001\end{array}$ & $\begin{array}{c}94.41 \pm 15.36 \\
\mathrm{p}^{\mathrm{a}}<0.0001\end{array}$ & $\begin{array}{c}86.84 \pm 17.53 \\
\mathrm{p}^{\mathrm{a}}<0.0001 \\
\mathrm{p}^{\mathrm{b}}<0.0001\end{array}$ & $\begin{array}{c}80.26 \pm 17.02 \\
\mathrm{p}^{\mathrm{a}}<0.0001\end{array}$ & $\begin{array}{c}95.08 \pm 14.59 \\
\mathrm{p}^{\mathrm{a}}<0.0001 \\
\mathrm{p}^{\mathrm{c}}<0.0001\end{array}$ & $\begin{array}{c}77.17 \pm 13.09 \\
\mathrm{p}^{\mathrm{a}}<0.0001\end{array}$ \\
\hline Superior & $127.78 \pm 17.78$ & $\begin{array}{c}115.43 \pm 22.55 \\
\mathrm{p}^{\mathrm{a}}<0.0001\end{array}$ & $\begin{array}{c}119.11 \pm 20.31 \\
\mathrm{p}^{\mathrm{a}}=0.0001\end{array}$ & $\begin{array}{c}113.27 \pm 24.14 \\
\mathrm{p}^{\mathrm{a}}<0.0001 \\
\mathrm{p}^{\mathrm{b}}=0.01\end{array}$ & $\begin{array}{c}105.95 \pm 24.08 \\
\mathrm{p}^{\mathrm{a}}<0.0001\end{array}$ & $\begin{array}{c}121.63 \pm 20.70 \\
\mathrm{p}^{\mathrm{a}}=0.03 \\
\mathrm{p}^{\mathrm{c}}<0.0001\end{array}$ & $\begin{array}{c}105.00 \pm \\
19.56 \\
\mathrm{p}^{\mathrm{a}}<0.0001\end{array}$ \\
\hline Inferior & $132.59 \pm 18.31$ & $\begin{array}{c}113.54 \pm 24.64 \\
\mathrm{p}^{\mathrm{a}}<0.0001\end{array}$ & $\begin{array}{c}118.51 \pm 20.91 \\
\mathrm{p}^{\mathrm{a}}<0.0001\end{array}$ & $\begin{array}{c}109.05 \pm 26.86 \\
\mathrm{p}^{\mathrm{a}}<0.0001 \\
\mathrm{p}^{\mathrm{b}}=0.0002\end{array}$ & $\begin{array}{c}99.81 \pm 25.91 \\
\mathrm{p}^{\mathrm{a}}<0.0001\end{array}$ & $\begin{array}{c}121.09 \pm 22.93 \\
\mathrm{p}^{\mathrm{a}}=0.0001 \\
\mathrm{p}^{\mathrm{c}}<0.0001\end{array}$ & $\begin{array}{c}94.24 \pm 20.16 \\
\mathrm{p}^{\mathrm{a}}<0.0001\end{array}$ \\
\hline Nasal & $85.57 \pm 19.38$ & $\begin{array}{c}74.35 \pm 19.80 \\
\mathrm{p}^{\mathrm{a}}<0.0001\end{array}$ & $\begin{array}{c}77.57 \pm 18.51 \\
\mathrm{p}^{\mathrm{a}}=0.0002\end{array}$ & $\begin{array}{c}71.73 \pm 20.16 \\
\mathrm{p}^{\mathrm{a}}<0.0001 \\
\mathrm{p}^{\mathrm{b}}=0.004\end{array}$ & $\begin{array}{c}66.96 \pm 17.96 \\
\mathrm{p}^{\mathrm{a}}<0.0001\end{array}$ & $\begin{array}{c}78.74 \pm 21.71 \\
\mathrm{p}^{\mathrm{a}}=0.02 \\
\mathrm{p}^{\mathrm{c}}<0.0001\end{array}$ & $\begin{array}{c}64.41 \pm 18.86 \\
\mathrm{p}^{\mathrm{a}}<0.0001\end{array}$ \\
\hline Temporal & $74.35 \pm 12.31$ & $\begin{array}{c}58.17 \pm 18.09 \\
\mathrm{p}^{\mathrm{a}}<0.0001\end{array}$ & $\begin{array}{c}63.33 \pm 17.14 \\
\mathrm{p}^{\mathrm{a}}<0.0001\end{array}$ & $\begin{array}{c}53.39 \pm 17.45 \\
\mathrm{p}^{\mathrm{a}}<0.0001 \\
\mathrm{p}^{\mathrm{b}}<0.0001\end{array}$ & $\begin{array}{c}48.01 \pm 17.37 \\
\mathrm{p}^{\mathrm{a}}<0.0001\end{array}$ & $\begin{array}{c}59.48 \pm 15.19 \\
\mathrm{p}^{\mathrm{a}}<0.0001 \\
\mathrm{p}^{\mathrm{c}}<0.0001\end{array}$ & $\begin{array}{c}45.00 \pm 16.29 \\
\mathrm{p}^{\mathrm{a}}<0.0001\end{array}$ \\
\hline
\end{tabular}

Values are mean $\pm \mathrm{SD}(\mu \mathrm{m}) . \mathrm{P}^{\mathrm{a}}$ are comparisons between MS eyes and controls. $\mathrm{P}^{\mathrm{b}}$ are comparisons between MS with ON and MS sans ON. $\mathrm{P}^{\mathrm{c}}$ are comparisons between MS affected eye and fellow eye. 


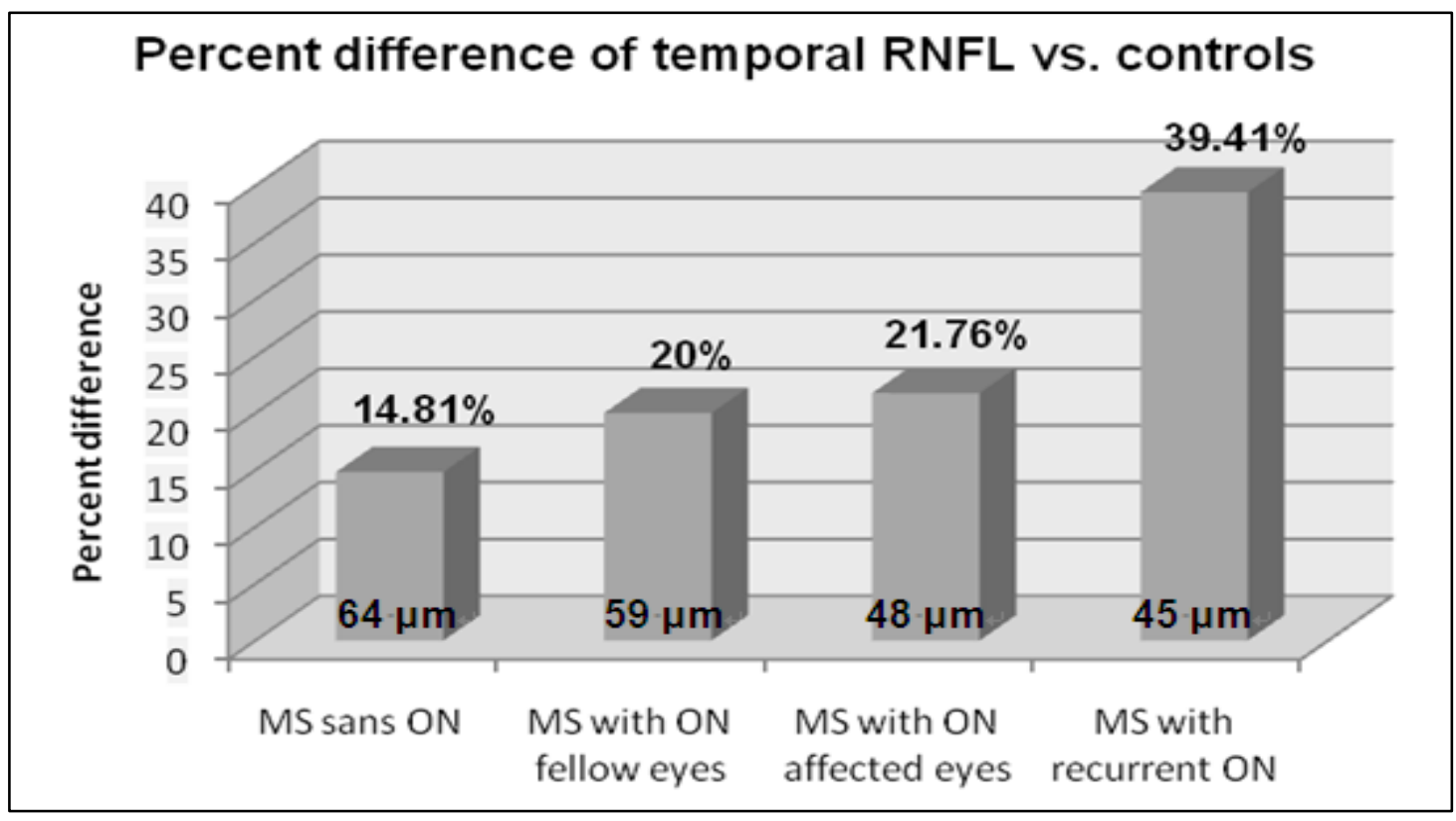

Percent difference $=\left(\right.$ mean $\mathrm{RNFL}_{\mathrm{MS} \text { patients }}-$ mean $\left.\mathrm{RNFL}_{\text {controls }}\right) /$ mean $\left.\mathrm{RNFL}_{\text {controls }}\right)$.

Figure 2. Percent difference of temporal RNFL measurements in the different MS subcohorts versus controls.

Table 2. OCT RNFL measurements in RRMS, all progressive MS (PPMS + SPMS), PPMS, SPMS.

\begin{tabular}{|c|c|c|c|c|}
\hline OCT RNFL & $\begin{array}{c}\text { RRMS } \\
(\mathrm{n}=446 \text { eyes })\end{array}$ & $\begin{array}{c}\text { All progressive MS } \\
(\mathrm{n}=87 \text { eyes })\end{array}$ & $\begin{array}{c}\text { PPMS } \\
(\mathrm{n}=43 \text { eyes })\end{array}$ & $\begin{array}{c}\text { SPMS } \\
(\mathrm{n}=44 \text { eyes })\end{array}$ \\
\hline Average thickness & $89.65 \pm 16.99$ & $\begin{array}{c}82.49 \pm 14.72 \\
\mathrm{p}^{\mathrm{a}}<0.0001\end{array}$ & $\begin{array}{c}87.83 \pm 11.73 \\
\mathrm{p}^{\mathrm{b}}=0.4\end{array}$ & $\begin{array}{c}77.25 \pm 15.57 \\
\mathrm{p}^{\mathrm{c}}<0.0001 \\
\mathrm{p}^{\mathrm{d}}=0.0006\end{array}$ \\
\hline Superior & $113.93 \pm 22.92$ & $\begin{array}{c}107.45 \pm 21.52 \\
\mathrm{p}^{\mathrm{a}}=0.01\end{array}$ & $\begin{array}{c}113.71 \pm 17.69 \\
\mathrm{p}^{\mathrm{b}}=0.9\end{array}$ & $\begin{array}{c}101.09 \pm 23.09 \\
\mathrm{p}^{\mathrm{c}}=0.0009 \\
\mathrm{p}^{\mathrm{d}}=0.006\end{array}$ \\
\hline Inferior & $112.12 \pm 25.10$ & $\begin{array}{c}105.79 \pm 21.86 \\
\mathrm{p}^{\mathrm{a}}=0.02\end{array}$ & $\begin{array}{c}114.44 \pm 15.58 \\
\mathrm{p}^{\mathrm{b}}=0.4\end{array}$ & $\begin{array}{c}97.93 \pm 24.13 \\
\mathrm{p}^{\mathrm{c}}=0.0005 \\
\mathrm{p}^{\mathrm{d}}=0.0003\end{array}$ \\
\hline Nasal & & $\begin{array}{c}68.53 \pm 17.85 \\
\mathrm{p}^{\mathrm{a}}=0.03\end{array}$ & $\begin{array}{c}73.07 \pm 19.56 \\
\mathrm{p}^{\mathrm{b}}=0.9\end{array}$ & $\begin{array}{c}63.39 \pm 13.74 \\
\mathrm{p}^{\mathrm{c}}<0.0001 \\
\mathrm{p}^{\mathrm{d}}=0.01\end{array}$ \\
\hline Temporal & $73.30 \pm 19.51$ & $\begin{array}{c}48.17 \pm 14.13 \\
\mathrm{p}^{\mathrm{a}}<0.0001\end{array}$ & $\begin{array}{c}50.37 \pm 12.14 \\
\mathrm{p}^{\mathrm{b}}<0.0001\end{array}$ & $\begin{array}{c}46.30 \pm 15.76 \\
\mathrm{p}^{\mathrm{c}}<0.0001 \\
\mathrm{p}^{\mathrm{d}}=0.2\end{array}$ \\
\hline
\end{tabular}

Values are mean $\pm \mathrm{SD}(\mu \mathrm{m}) . \mathrm{P}^{\mathrm{a}}$ are comparisons between RRMS and all progressive MS eyes. $\mathrm{P}^{\mathrm{b}}$ are comparisons between RRMS and PPMS. $\mathrm{P}^{\mathrm{c}}$ are comparisons between RRMS and SPMS. $\mathrm{P}^{\mathrm{d}}$ are comparisons between PPMS and SPMS.

Optical coherence tomography retinal nerve fiber layer (OCT RNFL) thickness in MS patients with recurrent optic neuritis

In MS patients with recurrent optic neuritis (MS recON), the RNFL was significantly reduced compared to controls, p-value range $<0.0001$ to 0.0015 (Table 1). Compared to MS patients with a single episode of optic neuritis, the following measurements were significantly thinner in MS recON patients: average thickness $(p=0.006)$, inferior $(p=0.003)$ and temporal quadrant $(\mathrm{p}=0.003)$.

Percent difference of quadrant RNFL measurements versus controls

Looking at the percent differences of the quadrant measurements from the healthy controls [percent difference $=\left(\right.$ mean $\mathrm{RNFL}_{\mathrm{MS}}$ patients - mean $\left.\mathrm{RNFL}_{\text {controls }}\right) /$ mean
$\left.\mathrm{RNFL}_{\text {controls }}\right)$ ], the temporal quadrant in all MS patients had the greatest thinning of $22 \%$ among all quadrants (superior $10 \%$, inferior $14 \%$, nasal $13 \%$ ) and to the average thickness (14\%). The degree of temporal quadrant RNFL thinning was least affected in the eyes of MS patients without optic neuritis $(15 \%)$ and was most severe in the eyes of MS patients with recurrent optic neuritis (39\%) (Figure).

Serial optical coherence tomography retinal nerve fiber layer (OCT RNFL) thickness in MS patients

There were 45 MS patients who had serial OCT without any intervening clinical optic neuritis. A total of 109 OCT scans were performed in this subcohort, with a mean of 2 OCT scans per patient, averaging 11 months apart. RNFL decreased by $3.4 \mu \mathrm{m}$ every 11 months $(3.7 \mu \mathrm{m}$ decrease per annum). In this subcohort, no significant difference was seen 
in the OCT RNFL measurements of those who have received MS therapy compared to those who have not been treated, except in the nasal quadrant $(\mathrm{p}=0.03)$.

Optical coherence tomography retinal nerve fiber layer (OCT RNFL) thickness in retrobulbar optic neuritis vs anterior optic neuritis

Papillitis was observed in 37 (40\%) of MS patients with optic neuritis. There was no significant difference in RNFL thickness measurements between MS patients with retrobulbar optic neuritis and those with papillitis, measured at least 9 months from the onset of clinical optic neuritis.

Optical coherence tomography retinal nerve layer (OCT RNFL) in MS subtypes

Progressive (primary progressive and secondary progressive) MS patients had significantly thinner OCT RNFL measurements compared to all relapsing-remitting MS (RRMS) patients: average thickness ( $p<0.0001$ ), superior quadrant $(\mathrm{p}=0.01)$, inferior quadrant $(\mathrm{p}=0.02)$, nasal quadrant $(\mathrm{p}=0.03)$, and temporal quadrant $(\mathrm{p}<0.0001)$ (Table 2). OCT RNFL measurements in secondary progressive MS (SPMS) patients were significantly thinner compared to RRMS patients: average thickness ( $p<0.0001)$, superior quadrant $(\mathrm{p}=0.009)$, inferior quadrant $(\mathrm{p}=0.005)$, nasal quadrant $(\mathrm{p}<0.0001)$, and temporal quadrant $(\mathrm{p}$ $<0.0001)$. PPMS patients had more OCT RNFL loss, except in the inferior quadrant, compared to RRMS patients, and was significantly thinner in the temporal quadrant ( $p$ $<0.0001)$. SPMS patients had significantly thinner OCT RNFL measurements compared to the PPMS group (average thickness $p=0.0006$, superior quadrant $p=0.006$, inferior quadrant $\mathrm{p}=0.003$, nasal $\mathrm{p}=0.01$ ), but not the temporal quadrant, $\mathrm{p}=0.18$.

\section{Comment}

We investigated optical coherence tomography (OCT) demonstrable axonal loss in patients with multiple sclerosis (MS) through measurements of the retinal nerve fiber layer (RNFL) of the optic nerve. The optic nerve, a frequent target in multiple sclerosis, is a useful in-vivo model of central nervous system axonal loss because within the retina, it is devoid of myelin31, 32 and can be easily evaluated through rapid non-invasive reproducible methods. As early as 1974, Frisén and Hoyt, 33 employed direct ophthalmoscopy to document RNFL atrophy in visually asymptomatic patients with multiple sclerosis. Kerrison et al found histopathologic evidence of retinal nerve fiber and optic nerve atrophy in $73 \%$ of patients affected with MS.34 Red-free photographs demonstrate defects of the RNFL in $50-80 \%$ of $\mathrm{MS}$ patients. 35,36

We observed a significant reduction in average RNFL thickness $(90 \mu \mathrm{m})$ in MS patients compared to disease-free controls, similar to values reported in previous studies ( 78 to $92 \mu \mathrm{m}) .37-39 \mathrm{MS}$ patients with a history of optic neuritis
(MSON) demonstrated a greater loss in RNFL thickness (87 $\mu \mathrm{m})$ versus controls. Trip et al40 reported an average RNFL in MSON eyes with incomplete visual recovery from optic neuritis of $68.7 \mu \mathrm{m}$; and their lower value likely reflects selection bias in this study. Furthermore, our cohort showed that recurrent attacks of optic neuritis advanced RNFL thinning $(77 \mu \mathrm{m})$.

Although all RNFL quadrant measurements were significantly thinner in MS patients compared to controls, this was most severe in the temporal quadrant. This finding is in agreement with data from prior OCT studies; 38, 41, 42 similarly, dilated funduscopy using a 90-diopter lens in eyes affected with ON43 and histopathologic studies of MS eyes reveal selective atrophy of the temporal portion of the optic nerve head.34 Sepulcre et. al, 39 studied a cohort of 61 patients with mild to moderate MS and noted significant RNFL thinning in all quadrants except the nasal; this finding may be confounded by age-related thinning of the RNFL across all quadrants,44-46 as the cohort was not compared to controls. Moreover, recurrent attacks of optic neuritis have more advanced RNFL thinning (average thickness $=78 \mu \mathrm{m}$, temporal quadrant $=46 \mu \mathrm{m}$ ).

The OCT software calculates the average RNFL thickness and compares these measurements with a normative age-matched database for patients aged 18 years or older. Based on this normative database, average and quadrant RNFL measurements are assessed as either normal (within the 5 th to 95 th percentile), above normal ( $>95$ th percentile), or below normal ( $<5$ th percentile). Our study has shown that only $23 \%$ of MS ON eyes were normal in all quadrants. RNFL loss occurs even in the absence of overt clinical optic neuritis.

Serial OCT was performed 45 MS patients without any intervening clinical $\mathrm{ON}$ in this cohort and revealed an overall average RNFL decrease of $3.7 \mu \mathrm{m}$ per annum. This number is greater than the normal RNFL thinning associated with age.44 Longitudinal studies are ongoing to determine the patterns of RNFL thinning over longer follow-up periods in MS, particularly in the absence of acute ON.

Progressive subtypes of MS show significantly thinner RNFL compared to RRMS, consistent with the theory that there is ongoing axon loss in progressive MS. Interestingly, SPMS patients lose significantly more RNFL than RRMS patients, but PPMS patients do not. This finding reflects the natural history of the disease subtypes. PPMS presents with myelopathy in $80 \%$ of cases, and a visual presenting symptom is uncommon; whereas in RRMS, and subsequently in SPMS, optic neuritis is the presenting symptom $25 \%$ of the time. 47

Multiple sclerosis is a disease of both demyelination and axonal loss. 48, 49 Our study demonstrates that measurement of the retinal nerve fiber layer using optical coherence tomography (OCT) documents optic nerve axon loss in patients with MS. OCT is a promising as non-contact, rapid, inexpensive, accurate, reproducible, readily available method to assess a common MS target. Since the OCT 
allows direct visualization of the RNFL, it enables the clinician to correlate structure to function by measuring other parameters of vision (e.g., visual acuity, electrophysiology, color vision, contrast sensitivity, low-contrast acuity, and visual fields), although these traditional measures of visual function often return to near normal despite RNFL loss (clinical - OCT visual "paradox") which reflects insensitivity of these conventional measures of visual function. Future studies should look into the role of OCT in following the pace of RNFL loss after optic neuritis and to establish its relationship with other clinical, laboratory and magnetic resonance imaging biomarkers.50 Finally, the OCT has the potential of becoming a surrogate marker51 for neuroprotective or disease-modifying drugs studies for MS, and with greater segmentation detail, will provide additional anatomic details about the course of MS.

\section{REFERENCES}

[1] Paty DW, Noseworthy JH, Ebers GC. Diagnosis of multiple sclerosis. In: Paty DW, Ebers GC (eds.). Multiple sclerosis. Contemporary neurology series. Philadelphia: FA Davis, 1997.

[2] Sørensen TL, Frederiksen JL, Brønnum-Hansen H, Petersen H. Optic neuritis as onset manifestation of multiple sclerosis: A nationwide, long-term survey. Neurology. 199; 53, 473-8.

[3] Shibasaki H, McDonald WI \& Kuroiwa Y. Racial modification of clinical picture of multiple sclerosis: comparison between British and Japanese patients. J Neurol. Sci. 1981; 49: 253-71.

[4] Kuroiwa Y \& Shibasaki H. Clinical studies of multiple sclerosis in Japan: I. A current appraisal of 83 cases. Neurology 1973 23: 609-17.

[5] Optic Neuritis Study Group. The Clinical Profile of Optic Neuritis: Experience of the Optic Neuritis Treatment Trial. Arch Ophthalmol. 1991; 109: 1673-8.

[6] Beck RW, Cleary PA, Anderson MM et al. A randomized, controlled trial of corticosteroids in the treatment of acute optic neuritis. The Optic Neuritis Study Group. New England Journal of Medicine. 1992; 326: 581-8.

[7] Cleary PA, Beck RW, Bourque LB, Backlund JC, Miskala PH, ONSG. Visual symptoms after optic neuritis. Results from the Optic Neuritis Treatment Trial. JNO. 1997; 17:18-28.

[8] Gartner S. Optic neuropathy in multiple sclerosis. Arch Ophthalmol. 1953; 50:718-26.

[9] Shindler KS, Guan Y, Ventrua E, Bennett J, Rostami A. Retinal ganglion cell loss induced by acute optic neuritis in a relapsing model of multiple sclerosis. Multiple Sclerosis. 2006; 12: 526-32.

[10] Guan Y, Shindler KS, Tabuena P, Rostami A. Retinal ganglion cell damage induced $y$ spontaneous autoimmune optic neuritis in MOG-specific TCR transgenic mice. J Neuroimmunology. 2006; 178:40-8.
[11] Hickman SJ, Brierley CMH, Brex PA et al. Continuing optic nerve atrophy following optic neuritis: a serial MRI study. Multiple Sclerosis. 2002; 8:339-42.

[12] Hickman SJ, Brex PA, Brierley CMH, Silver NC, Barker GJ, Scolding NJ, Compston DAS, Moseley IF, Plant GT, Miller DH. Detection of optic nerve atrophy following a single episode of unilateral optic neuritis by MRI using a fat-saturated short-echo fast FLAIR sequence. Neuroradiology. 2001; 43:123-8.

[13] Arnold DL \& Matthews PM. MRI in the diagnosis and management of multiple sclerosis. Neurology. 2000; 58(S4): S23-S31.

[14] Zivadinov R. Can imaging techniques measure neuroprotection and remyelination in multiple sclerosis? Neurology. 2997; 68 (Suppl 3):S72-S82.

[15] Losseff NA, Miller DH. Measures of brain and spinal cord atrophy in multiple sclerosis. J Neurol Neurosurg Psychiatry. 1998; 64(Suppl 1): S102-5.

[16] Simon JH, Jacobs LD, Campion MK, Rudick RA, Cookfair DL, Herndon RM, Richert JR, Salazar AM, Fischer JS, Goodkin DE, Simonian N, Lajaunie M, Miller DE, Wende K, Martens-Davidson A, Kinkel RP, Munschauer FE 3rd, Brownscheidle CM. A longitudinal study of brain atrophy in relapsing multiple sclerosis. The Multiple Sclerosis Collaborative Research Group (MSCRG). Neurology. 1999 Jul 13; 53(1):139-48.

[17] McFarland HF, Frank JA, Albert PS, Smith ME, Martin R, Harris JO et al. Using gadolinium-enhanced magnetic resonance imaging lesions to monitor disease activity in multiple sclerosis. Ann Neurol. 1992; 32:758-66.

[18] Trapp BD, Peterson J, Ransohoff RM, Rudick R, Mork S, Bo L. Axonal transection in the lesions of multiple sclerosis. $\mathrm{N}$ Engl J Med. 1998; 338: 278-85.

[19] Bjartmar C, Kinkel RP, Kidd G, Rudick RA, Trapp BD. Axonal loss in normal-appearing white matter in a patient with acute MS. Neurology. 2001; 57: 1248-52.

[20] Dutta R, Trapp BD. Pathogenesis of axonal and neuronal damage in multiple sclerosis. Neurology. 2007; 68(Suppl 3): S22-S31.

[21] Evangelou N, Konz D, Esiri MM, Smith S, Palace J, Matthews PM. Size-selective neuronal changes in the anterior optic pathways suggest a differential susceptibility to injury in multiple sclerosis. Brain. 2001; 124: 1813-20.

[22] Trapp BD, Ransohoff R, Rudick R. Axonal pathology in multiple sclerosis: relationship to neurologic disability. Curr Opin Neurol. 1999; 12:295-302.

[23] Budenz DL, Chang RT, Huang X, et al. Reproducibility of nerve fiber thickness measurements using the Stratus OCT in normal and glaucomatous eyes. Invest Ophthalmol Vis Sci. $2005 ; 46: 2440-3$

[24] Schuman JS, Pedut-Kloizman T, Hertzmark E, et al. Reproducibility of nerve fiber layer thickness measurements using optical coherence tomography. Ophthalmology. 1996; 103:1889-98.

[25] Poser CM, Paty DW, Scheinberg L et al. New diagnostic criteria for multiple sclerosis: guidelines for research protocols. Ann Neurol 1983; 13: 227-31. 
[26] Polman CH, Reingold SC, Edan G, Filippi M, Hartung HP, Kappos L, Lublin FD, Metz LM, McFarland HF, O'Connor PW, Sandberg-Wollheim M, Thompson AJ, Weinshenker BG, Wolinsky JS. Diagnostic criteria for multiple sclerosis: 2005 revisions to the "McDonald Criteria". Ann Neurol. 2005; 58: 840-6

[27] Hee MR, Izatt, JA, Swanson EA, et al. Optical coherence tomography of human retina. Arch Ophthalmol. 1995; 113:325-332.

[28] Huang D, Swanson EA, Lin CP, et al. Optical coherence tomography. Science. 1991; 254: 1178-1181.

[29] Fujimoto JG, Hee MR, Huang D, et al. Principle of optical coherence tomography in Optical Coherence Tomography of Ocular Diseases, $2^{\text {nd }}$ Ed. Schuman JS, Puliafito CA, Fujimoto JG (Eds). New Jersey, USA: SLACK Inc., 2004, pp 3-20.

[30] Beck RW, Cleary PA, Backland JC et al. The course of visual recovery after optic neuritis: experience of the Optic Neuritis Treatment Trial. Ophthalmology 1994; 101:1771-8.

[31] Duke-Elder S \& Cooke C. The differentiation of the neural ectoderm. In System of ophthalmology (Ed. Duke Elder S), Vol. 3, Pt. 1. Normal and Abnormal Development. 1963. St. Louis, USA: C.V. Mosby, pp. 81-126.

[32] Magoon EH \& Robb RM. Development of myelin in human optic nerve and tract. A light and electron microscopic study. Arch Ophthalmol. 1981; 99: 655-9.

[33] Frisén I, Hoyt WF. Insidious atrophy of retinal nerve fibers in multiple sclerosis: funduscopic identification in patient with and without visual complaints. Arch Ophthalmol. 1974; 98:1040-5.

[34] Kerrison JB, Flynn T, Green WR. Retinal pathologic changes in multiple sclerosis. Retina. 1994; 14:445-51.

[35] MacFadyen DJ, Drance SM, Douglas GR, Airaksinen PJ, Mawson DK, Paty DW. The retinal nerve fiber layer, neuroretinal rim area, and visual evoked potentials in MS Neurology. 1988; 38:1353-8.

[36] Elbøl P \& Work K. Retinal nerve fiber layer in multiple sclerosis. Acta Ophthalmol (Copenh). 1990; 68:481-6.

[37] Costello F, Couplan S, Hodge w, Lotello GR, Koroluk J, Pan YI, Freedman MS, Zackon DH, Kardon RH. Quantifying axonal loss after optic neuritis with optical coherence tomography. Ann Neurol. 2006; 59:963-9.

[38] Fisher JB, Jacobs DA, Markowitz CE, Galetta SL, Volpe NJ, Nano-Schiavi L, Baier ML, Frohman EM, Winslow H, Frohman TC, Calabresi PA, Maguire MG, Cutter GR, Bacler

\section{LJ. Ophthalmology. 2006; 113:324-32.}

[39] Sepulcre J, Murie-Fernandez M, Salinas-Alaman A, Garćia-Layana A, Bejarano B, Villoslada P. Diagnostic accuracy of retinal abnormalities in predicting disease activity in MS. Neurology. 2007; 68:1488-94.

[40] Trip SA, Schlottmann PG, Jones ST, Altmann DR, Garway-Heath DF, Thompson AJ, Plant GT, Miller DH. Retinal nerve fiber layer axonal loss and visual dysfunction in optic neuritis. Ann Neurol. 2005; 58: 383-91.

[41] Pro MJ, Pons ME, Liebam JM, Ritch R, Zafa S, Lefton D, Kupersmith MJ. Imaging of the optic disc and retinal nerve fiber layer in acute optic neuritis. J Neurol Sci. 2006; 250: 114-9.

[42] Parisi V, Manni G, Spadaro M, Colacino G, Restuccia R, Marchi S, Bucci MG, Pierelli. Correlation morphological and functional retinal impairment in multiple sclerosis patients. Invest Ophthalmol Vis Sci. 1999; 40:2520-7.

[43] Rath EZ, Rehany U, Linn S, Rumelt S. Correlation between optic disc atrophy and aetiology: anterior ischaemic optic neuropathy vs optic neuritis. Eye. 2003; 17: 1019-24.

[44] Parikh RS, Parikh SR, Sekhar C, Prabakaran S, Babu JG, Thomas R. Normal age-related decay of retinal nerve fiber layer thickness. Ophthalmology. 2007; 114: 921-6.

[45] Alamouti B, Funk J. Retinal thickness decreases with age: an OCT study. Br J Ophthalmol. 2003; 87:899-901.

[46] Jonas JB, Schmidt AM, Muller-Bergh JA, Schlotzer-Schrehardt UM, Naumann GO.Human optic nerve fiber count and optic disc size. Invest Ophthalmol Vis Sci. 1992; 33: 2012-8.

[47] Miller DH, Leary SM. Primary-progressive multiple sclerosis. Lancet Neurology. 2007; 6:903-12.

[48] Bjartmar C, Wujek JR, Trapp BD. Axonal loss in the pathology of MS: consequences for understanding the progressive phase of the disease. J Neurol Sci. 2003; 206:165-71.

[49] Bruck W, Stadelmann C. Inflammation and degeneration in multiple sclerosis. Neurol Sci. 2003; 24 (suppl 5): S265-7.

[50] Sergott RC, Frohman E, Glanzman R, AL-Sabbagh A, OCT in MS Expert Panel. The role of optical coherence tomography in multiple sclerosis: Expert panel consensus. J Neurol Sci. 2007 (in press).

[51] Katz R. Biomarkers and surrogate markers: An FDA perspective. NeuroRx. 2004; 1: 189-95. 